HStud 27 (2013)2, 263-276 DOI: 10.1556/HStud.27.2013.2.5

\title{
CROATIA AND SLAVONIA IN THE EARLY MODERN AGE*
}

\author{
SZABOLCS VARGA \\ College of Divinity, Pécs, Hungary \\ E-mail: szavarga@gmail.com
}

\begin{abstract}
Slavonia and Croatia belonged to the Habsburg controlled part of the Kingdom of Hungary. As a result of the Ottoman conquest, the two provinces merged into a single territorial entity, and this study discusses this process. The noble society and the public administration of Croatia and Slavonia had fewer and fewer links with the Hungarian institutions due to economic, religious and military reasons. However, in the meantime they established close relationships with the Habsburg dynasty and the Austrian hereditary provinces. The local nobility developed the idea of the independent Croatian state in the $16^{\text {th }}-17^{\text {th }}$ centuries, and thus, the territory could not reintegrate completely into the Kingdom of Hungary in the early $18^{\text {th }}$ century.
\end{abstract}

Keywords: early modern age, Kingdom of Hungary, Kingdom of Croatia, Habsburg monarchy, Ottoman conquest, development of the state, estate monarchy, Slavonia

This work deals with the history of the Kingdom of Croatia and Slavonia. Both geographic concepts have changed significantly in the past centuries. Croatia was a joint kingdom with the Kingdom of Hungary for eight centuries, while the latter was a most important province in historic Hungary. Present-day Croatia comprises regions and provinces of different cultures and pasts, which is also reflected in the country's coat of arms where the medieval coats of Ragusa (Dubrovnik), Dalmatia, Istria and Slavonia crown the gules and argent checkerboard of the escutcheon. It is impossible to show the early modern history of Croatia in a comprehensive framework, as the pasts of Istria, the Dalmatian cities under Venetian control and the independent Ragusa turned out differently, and the area of the medieval Kingdom of Croatia dominated by the Ottomans also developed differently from the remaining Croatia and Slavonia.

The two provinces transformed considerably in the early modern age: their area diminished, the majority of their population changed, their regions were re-

* The study was supported by the János Bolyai Research Scholarship (BO/00387/10/2). 
named and after their recapture, they only faintly resembled their medieval selves. The majority of medieval Croatia was still a border province of the Ottoman Empire in the $18^{\text {th }}$ century and these areas were increasingly often marked by maps as Bosnia. On a map drawn in 1688, only a narrow strip of land by the sea held by Christians and the southern area of the county of Zagreb lying between the River Sava and the River Una were called Croatia. Several decades had to pass until a map from 1799 marked the areas north of the Drava and west of the BabócsaKutina line as Croatia. However, the latter region can be termed Croatia only after 1920 , and thus, it is anachronistic to depict the $16^{\text {th }}$-century events from this aspect.

Slavonia also went under major territorial changes. The term Slavonia first referred to the western part of the area lying between the River Drava and the River Sava. This was recorded on Domenico Zenoi's military map drawn in 1566 and also on another one from 1640. However, the most precise maps were drawn on the Court Council of War's authority and the Italian architects, Natale and Paolo Angielini named the Slavonian areas controlled by Christians Vendvidék (Windischland) on their works $(1564,1574)$. The Speculum Orbis Terrae published by Cornelius de Jode in 1593 also used this name. The medieval counties of Pozsega, Baranya and Szerém were often mentioned as Rácország (Rascia) in the $17^{\text {th }}$ century parallel to the emerging "(Turkish) Slavonia" expression as one can trace on Joan Blaeu's map entitled Atlas Maior and published in 1662. By the time the Turks were expelled from the area, it had become a generally accepted custom to call the eastern areas lying between the Drava and the Sava Slavonia.

By that time the merging Croatia and Slavonia had drifted away from the Kingdom of Hungary in many aspects, although there were still close ties between them. Therefore, the Kingdom of Hungary, in fact, did not split into three but rather into four parts after the Ottoman conquest.

\section{Relationship between Croatia and the Kingdom of Hungary}

In the Middle Ages, Croatia covered the area lying between the Mountain Gvozd and the Adriatic Sea. Saint Ladislaus I occupied the territory in 1091 and put it under his nephew, Álmos's control. King Coloman finished Croatian extension when he crowned himself Croatian king in Biograd in 1102. In that year Croatia became a joint kingdom (pars annecta) of Hungary, and their fate joined inseparably for 800 years.

Due to the co-existence, Croatian nobles developed the myth of a common homeland and a certain "hungarus" consciousness, and they implied themselves into the notion Hungaria and regarded Hungarian kings as their own. Croats had also developed a strong cult of the Holy Crown, which was also demonstrable in 
the late $18^{\text {th }}$ century. It was not simply a religious cult because Croats (similarly to Hungarians) considered Saint Stephen's crown as the foremost attribute of their statehood. The doctrine of the Holy Crown of Hungary advocated that the Kingdom of Hungary and all the joined parts (real and demanded) belonged to the Holy Crown and were members (membrum) of it, and the king crowned by the Holy Crown got his power and royalty from the Crown.

Insistence on the Hungarian crown might arise from the fact that Croatian royal election had not become a tradition and it had disappeared without a trace. After the crowning ceremony in Székesfehérvár, Hungarian kings became the kings of Croatia as well and the titles King of Croatia and that of Dalmatia appeared among his titles in a foremost position. Croatian nobility was satisfied with the circumstances because Croatia never integrated into Hungary but remained a separate kingdom also a member of the Holy Crown. Despite the fact that their king was the Hungarian ruler, Croatian nobility always regarded their kingdom as independent. Therefore, Croatia was not a province but rather a joined part of Hungary, in spite of the fact that for the very reason of the difference in their size, they were not on a par.

There were close links between the two countries and their relationship cannot be described as a simple personal union. The independent Croatian royal court disappeared after 1097 and thus, Croats also lived in the medieval royal court, although it did not show any Croatian characteristics. There were not any government organizations specializing in Croatian affairs, neither formed an independent Chancellery or Chamber. The Royal Treasury and the Royal Chancellery competent in the whole territory of the Kingdom of Hungary dealt with the cases relating to the areas south of the River Sava.

The Royal Council operating in the court in Buda took decisions about the most important issues relating to the future of the country and they were the ones to decide upon the high ranking magistrates, the issue of war and peace and other diplomatic affairs. The Croatian-Dalmatian ban heading Croatia - Dalmatia came under Venetian rule in 1420, and thus, the Hungarian jurisdiction also came to an end - was also a member of the Royal Council and, following the palatine and the judge royal, was the third most prominent person of the Kingdom of Hungary. Although Croatian interests were represented by him in this important legislative body, his real significance lay in the fact that, relying on the royal estates in Croatia and in Dalmatia, the ban held enormous power. His influence was further increased by the fact that beside the armed forces he commanded due to his office, he also disposed over the royal and banderial armies mobilisable in the province. The ban was appointed by the king and only the members of the Royal Council could give their opinion on the chosen person. In the $15^{\text {th }}$ century, when several royal estates were taken over by nobles, the size of the ban's estates also increased in importance and the approval of the local nobility became essential. Therefore, 
by the Jagiellonian era, the king had to enter into negotiations about the ban's person who was chosen from the local aristocratic families.

The fact that the ban did not exercise unlimited authority in his territory also showed the close links surpassing a personal union. Since in the late Middle Ages the palatine claimed military and judicial jurisdiction over the whole territory of the Kingdom of Hungary, he could also take measures in Croatia and Dalmatia, moreover, from 1485 onward, the palatine held the office of the high judge of Dalmatia. As a result of the palatine's role, the ban cannot be regarded as a royal deputy in Croatia. The examples picked out also reveal that the medieval network of relations between the two countries was more complicated than in the case of a simple personal union. However, the Ottoman conquest and the development of the estates transformed this relationship in the early modern era.

\section{Slavonia in the Late Middle Ages}

The area stretching from the Mountain Gvozd to the River Drava was called Sclavonia, a country inhabited by the Slavs, as early as the $11^{\text {th }}$ century. It had probably come under Hungarian authority in the middle of the $10^{\text {th }}$ century.

In the $14^{\text {th }}-15^{\text {th }}$ century, Slavonia was headed by the Slavonian ban, who usually held other offices as well. He was often appointed as Croatian ban and this twin office-holding became a generally accepted custom in 1476. At the beginning, usually 2 people were elected to the position running two different apparatuses in the two provinces. Sometimes, the ban appointed a Slavonian nobleman as his Croatian vice-ban but the merger of the two offices had finished only by the middle of the $16^{\text {th }}$ century.

Medieval sources referred to the province as a regnum. However, it did not mean a kingdom, but it can rather be interpreted as a country inhabited by the Slavs. Its organization and position within the Kingdom of Hungary was somewhat similar to that of the voivodeship of Transylvania. The Hungarian county system was also introduced here. However, the greatest difference between the two systems was an intermediate level of administration (controlled by the ban) positioned between the county level and the central administration. However, the common law used in the province (unlike the one applied in Croatia) was in harmony with the Hungarian legal system.

The chief institution of the separate Slavonian nobility was the provincial assembly (congregation nobilium regni Sclavoniae). In the beginning, it was convoked on the orders of the king, but as of the $1450 \mathrm{~s}$, due to the weakening royal power, it could be regarded as an independent political authority passing decrees related to internal affairs. It was regularly convoked as of the Jagiellonian era when it had the right to discuss political issues, elect delegates, levy taxes or draw 
up petitions on behalf of the Slavonian nobility. The king sent special commissioners to the assembly to communicate his orders and represent his authority. Until the middle of the $16^{\text {th }}$ century, the Slavonian provincial assembly held its meetings separately from those of the Croatian Sabor. The merger of the two institutions in 1558 was also the result of the Ottoman conquest.

The inhabitants of Slavonia spoke different South Slav dialects. They consistently distinguished their Hungarian and Croatian villeins, which showed that they did not consider themselves as any of them but as Slavonian. The local nobility was multi-ethnical, the overwhelming majority of the big and medium landowners were of Hungarian origin with the exception of the areas of the county of Zagreb lying south of the Sava where Croatian big landowners acquired lands as early as the first decades of the $15^{\text {th }}$ century. Considerable Croatian immigration started only in the late $15^{\text {th }}$ century due to the Ottoman conquest. Presumably plenty of castle warriors and castle serfs belonged to the lesser nobility who fostered sense of particularism. Thus, it is possible that Slavonian particularism rooted in ethnic and legal peculiarities and resulted in the formation of the general assembly of the Slavonian nobility in the late $15^{\text {th }}$ century. Slavonian nobility included every person of noble origin having estates in the province - their estates entitled them to be members of the local noble community and identity. However, it is important to stress that the Slavonian nobility of heterogeneous origin was linked by the universal Latin culture and literacy as well as their marked hungarus consciousness. The lesser nobles in Slavonia shared the anti-German feelings of the Hungarian lesser nobility gathering in Rákosmezö and accepted John of Szapolyai's kingship in the months following the battle of Mohács. Historical traditions and the consciousness of their belonging to the Holy Crown proved to be so strong that the question of splitting off Hungary did not arise among them at all. However, the changes brought about by the Ottoman conquest weakened their links to the Kingdom of Hungary and offered them the possibility of redefining their constitutional status.

\section{The Impact of the Ottoman Conquest}

The Ottoman advance after the fall of Bosnia in 1463, with its day-to-day looting and plundering profoundly influenced the early modern history of Croatia and Slavonia. King Matthias I improved the border castle system developed by King Sigismund, organized the banates of Jajca and Srebernik in the Bosnian territory, established the captaincy of Zengg in 1469 with the center of Zengg (Senj) captured from the Frangepans and in 1476, merged the office of the ban of Croatia-Dalmatia with that of the ban of Slavonia. Although King Matthias was able to defend Slavonia to a certain extent with these measures, Croatian areas 
started to become deserted as the inhabitants moved to more northerly areas. Peasants and nobles both headed for safer places and their presence seriously influenced the ethnic composition of the area, moreover, Croatian nobility's sense of history played a key role in the future of Slavonia.

Neither King Matthias I, nor the Jagiellonian rulers could organize the adequate defense of the territory. The Croatian army led by ban Imre Derencsényi suffered a crushing defeat near Udbina on September $9^{\text {th }}$ 1493. Although this disaster did not result in territorial losses, it was regarded as the Mohács of the Croats and adversely influenced the relationship between Croatia and the Kingdom of Hungary. Croatian aristocrats possessing Slavonian estates became more and more distrustful of the royal court and increasingly often sought help from Venice and the Habsburg monarchy. Moreover, local nobility becoming more and more militarized in the constant warfare developed the idea of the "bulwark of Christianity". With reference to this view, they applied to Vladislav II for an own coat of arms in 1496, which proved to be an ideological base for their provincial separatism.

Helplessness against the numerical superiority of the Ottomans and countless military failures frustrated Croatian and Slavonian nobility with good reason, and they regarded the weakness of the Hungarian royal court and the arrogance of the Hungarian estates as the main reason for the problems. Contemporary sources and $17^{\text {th }}$-century interpretations reveal both issues and they might have caused the first break in Croats' positive view of Hungarians. Although the central government did everything it could, border defense was not efficient. The Ottomans captured Knin, the center of the medieval Kingdom of Croatia in 1522, and the Austrian Archduke Ferdinand (of Habsburg) had to spend more and more money on warfare. Therefore, Croatian nobility raised the question of free royal election in their political argument in 1527 , and mentioned it as a living possibility as of the death of King Zvonimir. At their meeting in Cetin on January $1^{\text {st }}$ they acknowledged Ferdinand as their king and formally broke with the Kingdom of Hungary. A Kingdom of Croatia separate from Hungary was of course a political fiction, Ferdinand made a claim on Croatia by means of the Holy Crown and the central administration did not change, either. The Hungarian Chamber continued to collect taxes, the palatine's jurisdiction still extended over Slavonia and Croatia and the royal judge was the supreme authority in all lawsuits. As the ideology of Croatian independence also determined the development of the Slavonian state, it is not in vain to dwell on the issue. Ferdinand first assumed the title rex Sclavoniae in 1529 and he used it permanently after 1542. On a twin royal seal made in 1558 for Ferdinand, this title followed that of the King of Croatia. Moreover, the Slavonian flag appeared in Maximilian's Hungarian coronation ceremony in 1563. Thus, by the first half of the $16^{\text {th }}$ century, Slavonia, surpassing the characteristics of the Transylvanian system, had developed the ideology and the symbols 
of authority of an independent kingdom (regnum Sclavoniae). Croatia, losing almost its whole territory but preserving the myth of independence, provided the model for the independent state, whose nobles, having moved to Slavonia, took part in provincial administration in growing numbers. This process went on until the $17^{\text {th }}$ century. However, in the meantime several Croatian-Slavonian aristocrats entered into the Habsburg imperial aristocracy while they similarly considered the Kingdom of Hungary as their homes. Due to their military and political roles, several Slavonian and Croatian nobles received baronies: the Ráttkays and Márk Horváth-Stancsics in 1559, the Draskovich family in 1567 and the Kasztellánfys in 1569. A large numbers of Hungarian letters were written by these families, many of whom served in the Hungarian theatre of war. Many Croatian-Slavonian lesser nobles appeared in their companies north of the Sava who preserved the idea of belonging to the Kingdom of Hungary well after their return.

\section{Different Ways of Development}

The so far discussed questions only partly explain why the new political formation drifted so far away from the Kingdom of Hungary. However, many events occurred differently in Slavonia than in the areas north of the Drava. These differences (military administration, the intensity of the war, the impact of the Reformation or the position of the Catholic Church) were strongly felt in everyday life.

During King Matthias's reign, the aids of the Holy See, then in the Jagiellonian era the financial support of Venice helped to defend Hungary against the Ottomans. However, after 1521, the Austrian Archduke Ferdinand became the most important supporter of the border defense system in the south. The defense of Croatia and Slavonia was of vital importance for the Austrian hereditary provinces, thus, they sent military aid to the area as early as 1522, and they appointed Niclas Graf zu Salm as the commander-in-chief of the Carniolan, the Carinthian and the Lower Austrian armies. Therefore, the defense against the Ottomans became twin controlled. While Salm's armies acted independently, the castles, the royal troops and the banderial armies were still led by the ban. Croatian aristocrats increasingly often entered into Ferdinand's service because he was the one who could afford to spend a significant sum on defense. Following the battle of Mohács, a lengthy debate on power took place between the royal commanders-in-chief delegated by Ferdinand and the officers being members of the Hungarian estates. Due to the Ottoman threat and the weakness of the province, the debate relatively early came to an end in Croatia as royal troops were sent to Senj and the castle of Klis in 1527 and Bihács (Bihać) also got out of the ban's control the following year. The "old Croatian military frontier" (alte krabatische Grenze) was first organized in 1538 under the leadership of Erasm von Thurn. At that time 
it did not extended over Slavonia but following the warfare of the 1540s, the system was improved. The reorganization was mainly the achievement of the commanders-in-chief sent to the Croatian-Slavonian area, notably that of Hans Ungnad, under whose leadership more and more border castles were taken over by the king, forming the basis of the Slavonian frontier (windische Grenze). While the defense of Hungarian and Slavonian territories was controlled uniformly in the 1540s, it was divided in 1550 for the sake of success. Although the bans and their troops also participated in the struggles, and Miklós Zrínyi, appointed in 1542 , was extremely successful in his fights, by that time defense was not based on these forces.

Permanent Ottoman advance made new changes necessary. Thus, Ferdinand appointed Hans Lenković as the commander-in-chief of the Croatian-Slavonian borderland. He controlled the reformed border defense system and the army paid by the hereditary provinces. The ban's authority considerably diminished as the border castles got out of his control - they were supplied by the Austrian hereditary provinces - and thus, he could rely only on the noble insurrection, the relatively weak troops sent by the counties and the ban's army of 4-500 soldiers. Border castles came under the control of the Inner Austrian Council of War (Innerösterreichischer Hofkriegsrat) in Graz in 1578, and the military frontier became reorganized with the centers Károlyváros (Karlovac) south of the Sava and Varasd (Varaždin). These territorial units were further divided into smaller captaincies in order to repel Ottoman attacks effectively.

Following the military reforms, bans were entrusted with new tasks: they had to defend the castles along the River Glina and the River Kulpa with their army of 500. After the fall of Bihać in 1592, these castles protecting the area formed the so-called Kulpa confines (banische Grenze) in the early $17^{\text {th }}$ century. Thus, the ban's jurisdiction became divided and they fulfilled their border defense duties as border captain-generals, which was also indicated by their new title (banus, necnon confiniorum Colapianorum, regni Sclavoniae supremus capitaneus). Since the castles controlled by the ban were financed by the war tax levied by the Croatian-Slavonian estates and other Hungarian incomes, they belonged to the Court Council of War in Vienna instead of the Council of War in Graz.

The minor changes made in the organization of the Croatian-Slavonian military frontier in the $17^{\text {th }}$ century did not touch its essence. Except for the Kulpa confines, the military frontier was financed and controlled by the War Council in Graz and Hungarian estates could not supervise or intervene in the processes. The majority of the peasant-soldiers serving in the territory were Orthodox vlachs/uskoks, and due to their collective rights, they managed to get out of the county system and the estates framework (a part of them in 1535, and the remaining group in 1630). Therefore, they were loyal exclusively to the Habsburg dynasty and the Habsburg military leaders. Because of their vital military role, Cro- 
atian-Slavonian nobility could neither consolidate nor abolish them. However, neither party expected the resolution of the problems from the Hungarian estates, but applied to the Habsburg ruler instead. The position of the Croatian ban was interwoven with the areas they were entrusted with. The military operations rarely allow the Croatian-Slavonian nobles emerged to the office to leave the territory, and the family residences of the Erdődys, the Keglevich and Draskovich families and the Zrínyis also lay in Slavonia. Their official duties forced them to visit Graz, Vienna or Bratislava and, except for some campaigns, they had no connection with the Hungarian public administration. As a result, military ties loosened between Croatia, Slavonia and the Kingdom of Hungary.

The intensity of frontier skirmishes was also different in Croatia and in Slavonia. The Lika and Krbava areas of Croatia became deserted as early as the late $15^{\text {th }}$ century. Scardona fell in 1522 and thus, the Ottoman forces were at an arm's length from the Adriatic Sea: they captured Obrovac in 1527 and Klis in 1537. As the Bosnian sancakbey Ferhad's troops occupied Cazin and Kladusa in 1576-78, Croatia lost the territory among the Rivers Una, the Glina and the Korana. Following the last wave of the Ottoman advance, after the fall of Ripacs and Hrasztovica in 1591 and Bihács in 1592, the River Kulpa marked the permanent border. The majority of the Croats fled to Italy, Western Hungary, the Austrian provinces and the remaining parts of Slavonia. Croatia lost almost 1 million people in the $16^{\text {th }}-17^{\text {th }}$ centuries. Vlach marauders settled in the deserted areas and many of them moved to the other, Habsburg-controlled side of the border in the $17^{\text {th }}$ century, increasing the considerable number of Orthodox peasant-soldiers.

The bloody war reached Slavonia a few decades later and it caused more serious damage than the one Hungarian areas had to suffer, except for Bács (Bač SRB), the military road along the Danube, and Inner Somogy. The enormous losses had geographic and political causes as well. Tens of thousands of people from Slavonia fled to safer areas as early as the 1530s, at a time when Ottoman forays spared other regions yet. The dense network of border castles and the many rivers made hostile advance difficult and thus, frontlines changed slowly. Nekcse (Našice) fell in 1541, Raholca (Orahovica) in 1542, Valpó (Valpovo), Pakrác (Pakrac) and Fejérkő (Bijela Stijena) were captured in 1543 while Velike (Kraljeva Velika) was occupied the next year. Verőce (Virovitica), Csázma (Čazma) and Dombró (Dubrava) were seized in the mid- $16^{\text {th }}$ century and the borderline was established on the western brink of Körös (Križevci) county in the next few decades. Permanent warfare made the conquered areas of Požega and Körös counties almost completely deserted. Ottoman defters showed that the population of the invaded territory had completely changed by the end of the $16^{\text {th }}$ century but the situation was very similar on the other side of the border, too. Vlach people from the Balkan moved to the deserted areas and fulfilled the task of bor- 
der defense as peasant-soldiers. However, their presence generated more and more problems.

Population change in the Slavonian areas occupied by the Ottomans also brought about major changes as the newcomers did not have memories of the medieval administrative system and the old landowners. Therefore, Christian taxation was impossible in the region and the so-called system of condominium could not develop except from a small area. It is not by chance that whereas data do not suggest the Islamisation of rural population north of the Drava, half of the population had been converted to Islam and 14 per cent of the people had become Orthodox in Slavonia and in Sriem by the last decades of Ottoman rule. The emigration of the aborigines blurred the borderline between the original church and lay administration units and thus, the new public administration had been established only by the middle of the $18^{\text {th }}$ century. However, the borderlines of the new administrative units rarely matched those of the medieval ones. Moreover, the majority of the Slavonian area was formed into a military frontier for the Orthodox border guards and therefore, the formerly uniform area became divided on denominational grounds. Christians could retain a territory of hardly 7000 square kilometers, and the war also made itself felt in the region. Due to the loss of the richest areas, only 3298 tax-paying plots could be listed in 1582 . The war stopped embourgeoisement, disarranged internal markets and the dense network of market towns thinned. Only big landowners could take part in long-distance trade: the Zrínyi and the Frangepán families traded with cattle, copper, salt and cloth. Poorer nobles attempted to have a share in army supplies. Although every landowner wanted to extend their allodial lands, they achieved limited success as big landowners settled more and more Croatian lesser nobles in their estates and put bigger and bigger lands in pawn in return for their military assistance. At the end of the $16^{\text {th }}$ century, Croatian lesser nobles held 48 percent of the plots in the county of Varasd (Varaždin) and their number had also tripled in the county of Zagreb. Social rise became even more difficult in these areas as landlords required produce in return for land usage and due to their pre-emptive rights they also prevented their civic-peasants from getting to the market. Corvée performed by villeins in border castles, lack of the prerequisites for peaceful production and excesses committed by landlords provoked discontent even among townsmen. The increase of burden led to many revolts, for instance in the abbey of Topuszkó (Topusko) between 1549 and 1555, and in Ferenc Tahy's estates between 1568 and 1572 - the ban's troops could defeat Matej Gubec's rebellious army of 15,000 only years after. It seems that the great losses suffered by the Croatian-Slavonian areas in the $16^{\text {th }}$ century did not allow the territory to enjoy the golden age of civic-peasant enterprises common in the Hungarian territory, which also weakened the links between the province and the Kingdom of Hungary. 
The most significant difference between the Kingdom of Hungary and Slavonia was the spread of the Reformation. While the popularity of the Protestant ideas swept the Hungarian areas, despite its early success it did not produce spectacular results in Slavonia. However, one should not forget about Stjepan Konzul and Antun Dalmatin's Gospel translations published in the ča dialect of the Istrian peninsula, and Primož Trubar's Croatian Bible. The printing house in Urach established by Hans Ungnad published several Protestant works and planned a mission into the Balkanian peninsula. György Zrínyi, who had been converted to Lutheranism with the Erdödy and the Batthyány families, established a short-lived printing house in Nedelistye (Nedelišće) in Meðimurje, which published a Croatian version of the Tripartitum among others. The conversion had lost much of its impetus by the end of the century, aristocratic families returned to their original religion, and lacking their support, preachers also had to leave. In the 1630s only a handful of people followed Protestant ideas.

Complicated reasons explain the different spread of the new ideas. It is important to note that Catholic hierarchy did not collapse in the region and the episcopal seat in Zagreb remained in Christian hands. Moreover, while in Hungary a considerable amount of Catholic wealth became secularized, the bishop of Zagreb remained one of the richest landowners in Slavonia. Besides, Catholic reform was also launched really early in the area: the Zagrebian bishop György Draskovich announced the decrees of the Council of Trent as early as 1574 and established a seminary in 1578 . The Catholic reform was helped by strong Italian cultural relations all the time. The center of Croatian clerical education was in Bologna where Paulus Zondinus established the Collegium Hungaricum et Illiricum in 1553. The Catholic Church - similarly to the Protestant denominations - became increasingly intellectual and the reformed monastic orders achieved considerable success in the field of pastoration and education. The Jesuits took up residence in Zagreb (1606) and in Varaždin (1633) where they also established colleges and a royal academy (1669) by Leopold I's permission. Capuchin monks settled in Zagreb in 1618, while Pauline monks established a grammar school in Lepoglava in 1582 which became upgraded as an institution of higher education (studium generale) in 1674. The strength of the Catholic hierarchy, the vicinity to Italy and the maintenance of schools reveal that Protestantism suffered a cultural defeat in Slavonia, similarly to the Catholic defeat north of the Drava.

Finally, let's throw a glance at the position of the Catholic Church. It is obvious that the Catholic Church reacted strongly against the Reformation but it had a still far more important role in Slavonia. Due to their power, Zagrebian bishops were appointed increasingly frequently as bans, and thus, ecclesiastical and lay power also concentrated in their hands. As a result of this, in 1567 the Slavonian estates enacted an act that forbade Protestants from acquiring estates and holding offices in Slavonia. Thus, southern Slav Catholicism managed to build a new element 
into the forming national ideology, because by the early $17^{\text {th }}$ century Catholic religion had become a cornerstone of the identity of the Croatian-Slavonian nobility set exactly against the Protestant Hungarian estates. Therefore, it is important to note that Catholicism has become a fundamental basis of modern Croatian national ideology not against Serbian Orthodoxy, but rather against Protestant Hungarian nationalism. The Croatian ban János Draskovich's (1595-1613) outburst against the extension of the freedom of worship over Slavonia at the Diet of Pozsony is an outstanding example of it. "He protested with invincible heart claiming he and the kingdom were ready to secede from the Kingdom of Hungary, rather than allowing this depraving plague to enter and ruin the country during his term of office". (Rattkay, 1772, 169) Therefore, the aforementioned aspects of the $16^{\text {th }}$-century events separated the future of the two countries, and neither the following centuries could reverse this process.

\section{Three Countries, One Homeland}

The idea of an independent south Slav kingdom, which had been developed by the chapter of Zagreb and accepted by the Croatian-Slavonian nobility, blossomed in the $17^{\text {th }}$ century. The process was facilitated by the fact that nobody knew exactly where the borders of the historical predecessor, Illíria lay and thus, the borderlines of the new state could be drawn up at will. Ráttkay in his cited work included Sriem and due to Miklós Zrínyi, the castle of Sziget into the concept of Slavonia. However, the fact that the Croatian-Slavonian estates had to face different problems than their Hungarian counterparts was a more significant element. Their most important problems were the Habsburg centralization, the Vlach question and the postponement of the Ottoman attacks. The Hungarian events, Bocskai's movement and the struggle against the Transylvanian princes displeased them because all of them drew the resources from the fight against the Ottomans and thus, they were not willing to cooperate with the Hungarian estates. The Statutum Valachorum (1630) granting widespread rights to Vlach peasant-soldiers, as well as the foreign control of the frontier were a breeding ground for distrust against the court in Vienna. This led to the Croatian ban (1640-46) and palatine (1646-48) János Draskovich's invitation to Ráttkay to prove the independent state status of the Illyrian areas. Although the work was finished, Péter Zrínyi and Ferenc Frangepán's execution temporarily dropped the matter of the formation of an independent Croatian-Slavonian kingdom with Ottoman help within the framework of the Habsburg Empire. However, the idea further blossomed and was spread by the Ladislaite Franciscan monks becoming independent in 1661, the big landowners embracing them, notably the Draskovich family and the Erdődys who particularly attracted by the Franciscan shrine in Tersatto. The 
greatest proponents of the case were the Zagrebian canons recruited from the Croatian-Slavonian nobility and the bishops of Zagreb, mainly Ferenc Ergelich (son of a Muslim converted into the Orthodox faith), Benedek Vinkovich (who studied in Bologna, at that time the citadel of Illyrism), Péter Petretich (educated in Samobor which was pastorated by the Franciscans) or Bogdan Martin (coming from Nart along the Sava). A common trait of these bishops was the fact that neither of their families belonged to the natio Hungarica and thus, they were not of the double or triple identity generally characterizing the aristocrats of the region. The Zagrebian bishop Martin Borkovich attempted to make the pope declare his diocese an archbishopric on the grounds of this idea. This step would have promoted independence from the Hungarian church organization, however, at that time it did not have any reality.

There were many elements missing from a Triune Kingdom. It did not have a permanent center because the ban did not have a residence until 1808. It also missed royal insignia and a coronation ceremony, although the first signs of them appeared in the inaugural ceremonies of the bans in the $17^{\text {th }}$ century and their carrying a scepter. The state would have also needed a king because the ban whose power had been the weakest ever since could not be regarded as a viceroy (prorex). Finally, one has to remember that the several centuries in a common homeland also left their marks on the Slavonian nobility because at that time many of them still supported a state belonging to the Kingdom of Hungary. Many more centuries had to pass until the bitter dream of an independent south Slav state could come true.

\section{References}

Bene, Sándor, 2000. Egy kanonok három királysága. Ráttkay György horvát históriája. [The Three Kingdoms of a Prebend]. Budapest: Argumentum.

Beuc, Ivan, 1985. Povijest institucija državne vlasti Kraljevine Hrvatske, Slavonije i Dalmacije. Zagreb: Pravni fakultet Zagreb.

Blažević, Zrinka, 2008. Ilirizam prije ilirizma. Zagreb, Golden Marketing - Tehnička knjiga.

Budak, Neven, 2007. Hrvatska i Slavonija u ranome novom vijeku. Zagreb: Leykam.

Klaić, Vjekoslav, 1988. Povijest Hrvata. Sv. 5. Zagreb: Nakladni zavod Matice Hrvatske.

Molnár, Antal, 2012. A zágrábi püspökség és a magyarországi katolikus egyház a 17. században. A püspöki processzusok tanúvallomásainak tanulságai [The Bishopric of Zagrab and the Hungarian Catholic Church in the Seventeenth Century. The Lessons of the Testimonies of the Episcopal Trials]. Budapest: METEM.

Pálffy, Géza, 2011. A haditérképészet kezdetei a Habsburg Monarchiában. Az Angielini várépítész-família rendszeres térképészeti tevékenysége a horvát-szlavón és a magyarországi határvidéken az 1560-1570-es években [The Beginnings of Military Cartography in the Habsburg Monarchy. The Regular Cartographic Activity of the Angielini Family of Castle Architects in the Border Regions of Croatia-Slavonia and Hungary in the 1560s-1570s]. Budapest: Archívum, Magyar Országos Levéltár. 
Pálffy, Géza, 2011. Magyar arisztokraták - horvát nemesek [Hungarian Aristocrats - Croatian Nobles]. História, 33 (5-6), 24-9.

Pálosfalvi, Tamás, 2011. Szlavónia a késő középkori Magyar Királyságban [Slavonia in the Hungarian Kingdom of the Late Middle Ages]. História, 33 (5-6), 19-24.

Rattkay, Georgius, 1772. Memoria regum et banorum regnorum Dalmatiae, Croatiae et Sclavoniae: inchioata ab origine usque ad praesentem annum MDCLII. Vindobonae.

Sokcsevits, Dénes, 2011. Horvátország a 7. századtól napjainkig [Croatia from the Seventh Century to the Present Day]. Budapest: Mundus Novus Könyvek.

Štefanec Nataša, 2011. Država ili ne, Ustroj Vojne krajine 1578. godine i hrvatsko-slavonski staleži u regionalnoj obrani i politici. Zagreb: Srednja Europa.

Varga, Szabolcs, 2008. Az 1527. évi horvát-szlavón kettős "királyválasztás” története [The History of the Dual Croatian-Slavonian "Election of the King"]. Századok, 142 (5), 1075-1134.

Varga, Szabolcs, 2013. Die Stellung Kroatiens innerhalb des Königreichs Ungarn in der frühen Neuzeit. Podravina, 13 (23), 77-96. 